\title{
TOLOK UKUR PENILAIAN MORAL DALAM ETIKA PRAGMATIK JOHN DEWEY
}

\author{
J. Sudarminta*
}

\begin{abstract}
Abstrak: Dalam artikel ini pandangan John Dewey tentang tolok ukur penilaian moral, sebagaimana ia jelaskan dalam teori etika pragmatiknya, akan disajikan dan dievaluasi. Artikel dibagi dalam tiga bagian. Pertama, berbeda dengan teori-teori etika teleologis, di mana moralitas tindakan dinilai dari menunjang tidaknya tindakan tersebut dalam upaya mencapai tujuan akhir hidup manusia, dalam pandangan Dewey, suatu tindakan dinilai secara moral baik kalau tindakan tersebut mencapai tujuan yang dimaksudkan untuknya. Tujuan tersebut bersifat kontekstual dan plural serta selalu terkait dengan sarana yang tersedia untuk mencapainya. Kedua, bagi Dewey suatu tindakan dinilai baik atau benar secara moral kalau menunjang proses perwujudan diri si pelaku tindakan. Apa yang menunjang proses perwujudan diri si pelaku tindakan tak pernah dapat ditentukan secara a priori berdasarkan konsep kodrat manusia. Dalam memahami manusia, Dewey menolak paham esensialisme kondrat manusia. Ia memahami pengertian perwujudan diri manusia dalam konteks proses "transaksi" manusia sebagai organisme dengan lingkungan hidup sekitarnya. Ketiga, sebuah evaluasi terhadap pandangan Dewey mengenai tolok ukur penilaian moral dalam teori etika pragmatiknya akan disajikan.
\end{abstract}

Kata-kata kunci: Etika, penilaian moral, organisme, lingkungan, endsin-view, pengembangan diri, tradisi moral, pragmatisme, naturalisme, transaksi.

Abstract: In this article John Dewey's criteria for moral judgment, as he expounds in his pragmatic ethics, will be presented and evaluated. The article will be divided into three parts. First, different from traditional teleological ethics, in which the morality of an act is judged from the

* J. Sudarminta, Direktur Pascasarjana Sekolah Tinggi Filsafat Driyarkara, Cempaka Puth Indah 100 A, Jembatan Serong, Rawasari, Jakarta 10520. E-mail:jsudarsj@gmail.com. 
point of view of certain human final end, an act, in Dewey's view, should be judged as morally good if it achieves its specific and contextual endin-view. There are many ends-in-view as there are many moral acts, and an end-in-view can never be determined apart from its actually available means to achieve it. Second, for Dewey, an act is considered good or morally right if it does in practice lead to the human self-realization of the agent. What constitutes an agent's human self-realization can never be determined in a priori way. Dewey rejects essentialism of human nature in understanding human being. He understands human self-realization within the context human dynamic process of "transactions" with his or her concrete environment. Third, an evaluation of Dewey's view will be provided.

Keywords: Ethics, moral judgment, organism, environment, ends-in-view, self-realization, moral tradition, pragmatism, naturalism, transaction.

\section{PENDAHULUAN}

Menurut John Dewey, maksud dirumuskannya suatu etika atau teori moral adalah untuk "memberi penjelasan sistematis terhadap penilaian dan putusan kita tentang perilaku manusia, sejauh itu dinilai dari segi benar atau salahnya, baik atau buruknya."1 Berdasarkan pernyataan ini kiranya wajar kalau kita mencari tahu tentang tolok ukur penilaian moral sebagaimana ia kemukakan dalam etikanya. Perilaku macam apa oleh Dewey dinilai baik atau benar secara moral? Bagaimana ia membuat penilaian dan putusan itu? Dengan kata lain, mana tolok ukurnya dalam membuat penilaian dan putusan moral?

Dalam kebanyakan teori moral, jawaban atas pertanyaan-pertanyaan semacam itu tidak sulit untuk ditemukan karena biasanya pertanyaan-pertanyaan macam itulah yang dicoba untuk ditanggapi oleh pengarangnya. Akan tetapi tidak demikian halnya dalam teori moral John Dewey. Bukunya yang berjudul Theory of the Moral Life lebih

1 John Dewey, Theory of The Moral Life (New York: Holt, Rinehart and Winston, Inc. 1960), p. viii. 
merupakan suatu dialog dan kritik terhadap teori-teori etika yang lain, sedangkan gagasannya sendiri hanya muncul secara terpotong-potong di sana-sini sambil lalu. Maka untuk memperoleh kejelasan tentang tolok ukur baik-buruk dan benar-salah dalam teori moralnya, kita perlu menempatkan telaahnya tentang moral dalam keseluruhan konteks filsafatnya yang secara umum tergolong dalam aliran Pragmatisme dan Naturalisme.

Tulisan ini akan dibagi dalam tiga bagian. Pertama, tolok ukur penilaian moral dalam etika pragmatik John Dewey akan dibicarakan dari perspektif objek tindakan atau tujuan yang mau dicapai. Kedua, tolok ukur tersebut akan dibicarakan dari perspektif subjek tindakan atau pribadi pelaku moral. Ketiga, beberapa catatan kritis sebagai tanggapan terhadap pemikiran Dewey akan diberikan.

\section{TUJUAN-YANG-DIRENCANAKAN (ENDS-IN-VIEW)}

Dalam teori-teori moral teleologis pada umumnya, suatu tindakan secara moral disebut baik kalau tindakan itu menunjang perwujudan atau membawa ke arah pencapaian tujuan akhir (final end) sebagai kebaikan tertinggi yang dicita-citakan. Apabila tujuan akhir sebagai kebaikan tertinggi ini sudah dapat ditentukan, maka penilaian dan putusan moral nampaknya dengan cukup mudah dapat dilakukan. Bagi seorang pragmatis seperti Dewey yang mempunyai keprihatinan besar tentang bagaimana sesuatu secara konkret dapat dilakukan dalam praktik, penilaian dan putusan moral tidaklah semudah seperti yang secara abstrak dibayangkan. Di mata Dewey, teori-teori moral tradisional ${ }^{2}$ telah membuat kekeliruan dengan menyibukkan diri dan berkutat dengan spekulasi tentang tujuan akhir dan tentang standar terakhir untuk menentukan benar dan salahnya, baik dan buruknya perilaku manusia. Menurutnya, spekulasi macam itu selain hanya akan membawa kepada

2 Dewey cenderung membuat pernyataan-pernyataan yang bersifat merampat (generalisasi).Yang dia maksudkan dengan "teori-teori moral tradisional" itu persisnya macam apa atau siapa contoh pencetusnya dalam sejarah kadang tidak jelas. 
perdebatan yang berkepanjangan tentang mana yang disebut sebagai tujuan akhir dan kebaikan tertinggi, ternyata juga telah membawa akibat tragis berupa pemisahan dan isolasi kegiatan etika dari pengalaman konkret manusia di dunia nyata sehari-hari. Pemisahan itu ternyata juga telah membawa keterpecahan dalam diri manusia sendiri.

Dalam analisis Dewey, spekulasi tentang tujuan akhir dan kebaikan tertinggi sebagai standar terakhir penentuan baik-buruknya perilaku manusia itu didasarkan atas suatu kepercayaan akan adanya finalitas dari segala sesuatu dalam alam sebagaimana telah dibayangkan oleh Aristoteles. Menurut pendapat Dewey, kepercayaan macam itu tidak lebih hanyalah warisan intelektual budaya feodal-atistokratis yang secara historis semakin memudar. Spekulasi itu juga didasarkan atas pandangan kosmologis yang memahami alam dunia sebagai suatu yang jelas batas-batasnya, tertata hirarkis rapi dari sana-nya di mana permanensi dianggap lebih unggul dan sejati dibadingkan dengan gerak perubahan; suatu pandangan kosmologis yang menurut dia semakin ditinggalkan oleh sains kealaman. ${ }^{3}$ Kepercayaan akan adanya tujuan tertentu dalam alam, akan adanya nilai-nilai yang tetap tak berubah lepas dari aktivitas konkret manusia telah melahirkan pemisahan antara apa yang disebut kebaikan intrinsik dan kebaikan instrumental, apa yang sungguh-sungguh bernilai pada dirinya sendiri dan apa yang hanya bernilai sebagai sarana atau alat untuk sesuatu yang lain. Secara historis pemisahan itu, yang nampaknya tak ada ruginya, ternyata telah menjadi sumber dan dasar pembenaran untuk secara tegas membuat pemisahan antara kebaikan-kebaikan ideal dan kebaikan yang melulu material, apa yang sungguh punya nilai moral dan apa yang melulu duniawi. Pemisahan antara kebaikan moral dan kebaikan material itu ternyata telah membuat apa yang disebut kebaikan moral menjadi begitu tipis dan kurus atau, kalau tidak, menjadi tak terjangkau dan terlalu mewah, karena terlalu jauh dari pengalaman konkret kehidupan manusia. Sebaliknya, kehidupan manusia dalam dunia material menjadi semakin

3 John Dewey, Reconstruction In Philosophy (Boston: Beacon Press, 1972), pp. 53-61; 161. 
buruk dan brutal: “Tak seorang pun dapat membayangkan betapa semakin buruk dan brutalnya kehidupan ekonomi kita justru karena tujuan-tujuan ekonomis hanya dianggap melulu sebagai sarana."4

Sebagai ganti spekulasi tentang tujuan akhir tertentu entah dalam alam atau dalam pikiran manusia (tujuan metafisis), John Dewey mengusulkan apa yang dia sebut tujuan-tujuan yang dibayangkan atau direncanakan untuknya (ends-in-view). ${ }^{5}$ Tujuan yang dibayangkan atau tujuan sejauh terlihat dalam konteks situasi permasalahan yang dihadapi ditentukan setiap kali ada sesuatu yang harus dilakukan: "Kebaikan moral dan tujuan [tindakan moral] hanya ada manakala sesuatu harus dilakukan. Fakta bahwa sesuatu harus dilakukan membuktikan bahwa ada kekurangan, ada keburukan dalam situasi yang senyatanya ada." 6 Dalam pandangan ini penyelidikan yang saksama terhadap keseluruhan aspek pokok dari situasi konkret yang problematis merupakan langkah yang penting, dan semua kegiatan untuk mencapai tujuan dalam konteks situasi tersebut bukanlah sekadar sarana. Menurut Dewey, nilai suatu tujuan cukup banyak ditentukan oleh sarana yang digunakan untuk mencapainya. Nilai suatu tujuan berbeda-beda menurut macam-macam kemungkinan sarana yang dapat digunakan untuk mencapai tujuan tersebut. ${ }^{7}$ Sesuatu hanya dapat diantisipasi atau dilihat sebelumnya sebagai tujuan atau hasil yang mau dicapai dalam kaitan dengan sarana yang mau dipakai untuk mencapainya. Tak mungkin suatu end-in-view dirumuskan atau suatu hasil proses kegiatan tertentu diantisipisikan

$4 \quad$ Ibid. pp. 171.

5 John Dewey, Experience and Nature (La Salle, Ill: Open Court, 1971), pp. 80-101. Kata 'ends' sengaja ditulis dalam jamak karena bagi Dewey tujuan itu tidak hanya satu, melainkan banyak sesuai dengan macam-macam situasi problematis yang dihadapi manusia dalam berbagai lingkungan hidupnya.

6 Dewey, Reconstruction of Philosophy, pp. 169.

7 John Dewey, The Theory of Valuation (Chicago: University of Chicago Press, 1939), khususnya Bab VI: "The Continuum of Ends-Means." Juga dalam bukunya Experience and Nature, Bab IV. 
tanpa sama sekali memikirkan sarana yang mau dipakai untuk mencapainya.

Berkenaan dengan kegiatan deliberasi moral untuk mengenali dan menentukan ends-in-view berdasarkan sarana yang secara konkret tersedia atau dapat diupayakan dalam konteks situasi permasalahan yang ada, Dewey memahami peran dan urusan pokok etika. Menurutnya, peran dan urusan pokok etika bukan memberikan suatu teori tentang tujuan akhir, kebaikan dan nilai-nilai yang tetap dan baku, melainkan menyajikan suatu teori kritik yang memberi metode untuk menganalisis situasi guna memilah-milah dan memilih di antara kemungkinan-kemungkinan kebaikan dan nilai yang dapat diwujudkan berdasarkan kondisi konkret yang ada. Metode yang dia maksud adalah apa yang ia sebut "method of intelligent action," yaitu metode ilmiah berupa pengamatan empiris, teori sebagai hipotesis dan uji coba ekperimental sejauh metode itu dapat diterapkan dalam penilaian dan putusan praktis.

Dewey berpendapat bahwa penilaian dan putusan moral dalam teori-teori moral tradisional, dalam mana baik-buruknya perilaku manusia dinilai berdasarkan tujuan akhir yang sudah tetap dan baku, cenderung membuat orang tidak lagi kritis dan kreatif untuk melihat kemungkinan-kemungkinan adanya tujuan dan nilai-nilai baru. Mereka sekadar mengikuti kebiasaan, aturan dan wujud-wujud keutamaan yang sudah diwarisi dari masa ke masa. Dewey memang tetap menghargai nilai tradisi sebagai endapan kebijaksanaan pengalaman masa lalu dan titik tolak untuk deliberasi selanjutnya, tetapi nilainya bersifat intelektual dan analitis. Tradisi moral yang antara lain memuat klasifikasi keutamaan-keutamaan moral atau kebaikan (seperti keadilan, persahabatan dan patriotisme) menunjukkan kemungkinan nilai yang perlu diperhatikan dalam menghadapi situasi khusus. Tradisi moral memunculkan metode tindakan yang dapat dicoba dalam memerangi sebab-sebab kejahatan yang sekarang dihadapi.

Memahami tujuan atau kebaikan moral sebagai ends-in-view atau tujuan kontekstual, menurut Dewey, tidak hanya membuat orang 
bersikap lebih sadar dalam bertindak, kritis dan terbuka terhadap kemungkinan-kemungkinan baru, tetapi penilaian moral berdasarkan tercapai tidaknya ends-in-view juga membuat penilaian terhadap perilaku seseorang tidak kejam dan kurang hati-hati. Alasannya adalah karena situasi konkret yang mengkondisikan si pelaku moral juga ikut dipertimbangkan. Penilaian moral macam ini juga dapat membebaskan orang dari sikap hipokrit karena masing-masing pelaku moral ditantang untuk memilih dan menentukan sendiri ends-in-view yang secara objektif dan konkret dituntut dalam situasi problematis yang dihadapi dan bukan hanya melakukan apa yang biasanya diharapkan orang untuk dilakukan.

Gagasan Dewey tentang ends-in-view sebagai alternatif terhadap tujuan akhir yang sudah bersifat tetap dan baku, didasarkan atas paham pemikirannya yang ia sebut "naturalisme empiris" atau "empirisme naturalistik." Dalam paham tersebut manusia ia gambarkan sebagai organisme yang secara internal berinteraksi dengan lingkungannya:

Suatu pertimbangan pokok pertama yang perlu diperhatikan adalah kenyataan bahwa hidup berlangsung dalam suatu lingkungan hidup; tidak hanya dalam lingkungan hidup, tetapi juga berkat lingkungan hidup, melalui interaksi dengannya. ... Karir dan nasib makhluk hidup terkait dengan pertukarannya dengan lingkungan hidup sekitarnya, tidak hanya secara eksternal tetapi secara internal. ${ }^{8}$

Hidup merupakan suatu proses interaksi dengan alam yang terus berubah. Dalam proses interaksi itu baik organisme maupun alam berubah, berkembang dan diperkaya. Ends-in-view terbentuk sebagai realisasi interaksi tersebut.

Dalam proses interaksi antara organisme dengan lingkungan hidupnya terdapat ritme pergantian antara saat yang oleh Dewey disebut disorientation dan reintegration. Saat disorientation terjadi ketika keseimbangan antara organisme dan proses alam lingkungannya yang terus berubah terganggu sehingga muncul kebutuhan untuk memulihkan

8 John Dewey, Art As Experience (New York: Capricorn Books, G.P. Putnam's Sons, 1958), p. 13. 
kembali keseimbangan antara keduanya. Kegiatan memulihkan kembali keseimbangan itu disebut reintegration. Dalam proses reintegrasi inilah ends-in-view terbentuk atau diproyeksikan dengan merujuk pada keinginan, kebutuhan, kekurangan, konflik dan masalah yang secara konkret muncul dalam proses interaksi. Dicapainya ends-in-view, sebagai proyeksi kosekuensi atau akibat-akibat yang mungkin dari tindakan yang diambil dalam konteks situasi problematis yang dihadapi, dialami sebagai pemenuhan, kepuasan, atau pemulihan kembali keseimbangan. Ketika ends-in-view tercapai, situasi problematis atau saat disorientasi yang menuntut reintegrasi sudah diatasi. Dalam konteks pencapaian endsin-view, suatu tindakan dinilai baik apabila akibat-akibat yang dapat diproyeksikan dari tindakan tersebut dapat memuaskan kebutuhankebutuhan nyata, menyelesaikan konflik yang dialami, memecahkan masalah yang dihadapi, memperbaiki keburukan yang ada dalam masyarakat dan meningkatkan kesejahteraan umum. ${ }^{9}$

Suatu end-in-view selalu dilihat dalam perspektif sosial-historis tertentu dan terbuka terhadap perkembangan selanjutnya, karena dalam pemahaman Dewey pencapaian end-in-view sebagai suatu puncak pemenuhan (consummation) merupakan suatu keseimbangan yang bergerak. Pencapaian suatu end-in-view sebagai puncak pemenuhan merupakan akhir dari proyek kegiatan sebelumnya, tetapi sekaligus juga merupakan awal dari proyek kegiatan selanjutnya. Bagi Dewey, yang pemikirannya sangat dipengaruhi oleh paham evolusi Darwin serta paham kemajuan dalam abad ke-19, proses pertumbuhan, perbaikan keadaan yang sudah ada, atau kemajuan merupakan nilai yang lebih penting dibandingkan dengan hasil yang statis. Ia bahkan menyatakan: "Growth itself is the only moral 'end'."10 Sesuai dengan pernyataan ini, bagi Dewey suatu tindakan disebut baik kalau tindakan itu menunjang pertumbuhan.

9 Dewey, Theory of Valuation, pp. 46-47; Reconstruction of Philosophy, p. 178.

10 John Dewey, Reconstruction of Philosophy, p. 177. 
Sebelum berpindah ke pembicaraan tentang tolok ukur penilaian baik-buruk dan benar-salah dalam teori moral Dewey dilihat dari perspektif subjek pelaku tindakan, ada baiknya kalau gagasan pokok dalam bagian pertama dirangkum. Pertama, telah kita lihat bahwa dalam pemikiran Dewey, baik atau buruknya suatu tindakan secara moral tidak dapat dinilai dan diputuskan secara a priori lepas dari situasi konkret yang melingkupi tindakan tersebut. Pertanyaan tentang apa yang baik secara moral dan apa yang semestinya dijadikan tujuan kegiatan hanya muncul manakala sesuatu harus dilakukan. Kebaikan dan kewajiban moral secara konkret bersifat kontekstual. Kedua, baik-buruknya suatu tindakan perlu dinilai dan diputuskan berdasarkan akibat-akibat tindakan tersebut sebagaimana diproyeksikan dalam tujuan yang dibayangkan (end-in-view) dalam konteks permasalahan yang dihadapi dan tidak berdasarkan tujuan akhir yang sudah tetap dan baku bagi setiap manusia (fixed and final end). Ketiga, suatu tindakan dinilai baik kalau mencapai tujuan yang dibayangkan dalam deliberasi moral, dan hal itu bisa dikenali dari apakah akibat tindakan itu dalam kenyataan konkret dialami sebagai pemuasan suatu kebutuhan nyata, pemenuhan suatu kekurangan, perbaikan keadaan, dan menunjang pertumbuhan.

\section{PERKEMBANGAN DAN PERWUJUDAN DIRI SEBAGAI MANUSIA}

Dalam teori moralnya, Dewey sangat menekankan kesatuan hakiki antara diri moral si pelaku tindakan dan tindakannya. ${ }^{11}$ Yang satu tidak dapat dilihat melulu sebagai sarana bagi yang lain. Kesatuan tersebut mendasari semua putusan yang secara khas bersifat moral. Setiap putusan moral selalu merupakan suatu ungkapan atau pewahyuan tentang diri si pelaku moral, dan setiap tindakan moral selalu berakibat pada pembentukan diri si pelaku moral. Dalam tindakan menilai dan mengambil putusan secara moral, seseorang menentukan dan membentuk wataknya: "Sepintas lihat, pertimbangan yang berakhir pada pilihan

11 Dewey, Theory of the Moral Life, p. 151.

12 Ibid., p. 149. 
[tindakan moral] itu menyangkut bobot nilai objek atau tujuan tertentu yang mau dicapai. Akan, tetapi sesungguhnya di balik itu semua adalah sebuah proses menemukan pribadi macam apa si pelaku moral itu berhasrat untuk menjadi."12 Berdasarkan pernyataan ini dapat disimpulkan bahwa bagi Dewey memilih tindakan yang benar secara moral atau berbuat yang baik pada dasarnya adalah memilih tindakan yang menunjang perkembangan dan perwujudan dirinya sebagai manusia. Berbeda dengan Aristoteles atau pun Thomas Aquinas yang juga bicara tentang etika pengembangan diri tetapi mendasarkannya pada finalitas kodrat manusia, Dewey menolak paham essensialisme dalam memahami manusia. Seperti sudah dikemukakan di atas, ia menolak adanya tujuan akhir yang sudah tetap dan baku bagi manusia dan memilih apa yang ia sebut ends-in-view. Dalam kaitan dengan ini, perkembangan dan perwujudan diri sebagai manusia dia mengerti dalam konteks aspek dinamis kepribadian manusia dalam interaksi atau kadang ia menyebutnya "transaksi"-nya dengan lingkungan. Yang menunjang proses perkembangan dan perwujudan diri manusia adalah tindakan yang mewujudkan ends-in-view, yakni tujuan-tujuan kegiatan yang dalam perspektif perkembangannya sampai sekarang diperhitungkan akan menunjang proses reintegration dalam lingkungan atau memulihkan equilibrium yang terganggu.

Persoalan yang muncul adalah bagaimana memilih tindakan yang benar atau nilai yang sejati sehingga tindakan itu akan menunjang perkembangan dan perwujudan diri si pelaku moral. Persoalan ini sangat nyata karena setiap orang sering dihadapkan pada macam-macam objek pilihan dan kadang juga mengalami konflik nilai dan konflik keinginan. Dalam menanggapi persoalan tersebut, Dewey membedakan kebaikan yang kebetulan diinginkan, dihargai dan dinikmati (the good as desired, valued, and enjoyed) dari kebaikan yang setelah dipikirkan masak-masak dengan mempertimbangkan berbagai konsekuensi yang terkait, memang pantas diinginkan, sungguh-sungguh berharga dan layak dinikmati (the good which is desirable, valuable, and enjoyable). Bagi Dewey kebaikan yang sejati atau yang sungguh-sungguh bernilai adalah kebaikan yang tahan 
uji dalam refleksi yang mempertimbangkan kebaikan yang diinginkan itu dalam kaitannya dengan kepentingan orang banyak. Seorang pelaku moral semakin mengembangkan dan mewujudkan dirinya sebagai manusia apabila tindakannya mengindahkan hubungannya dengan orang lain dan sedapat mungkin memperkaya pengalaman semua pihak yang terkait dalam lingkungan hidupnya.

Dewey juga mengajarkan bahwa setiap orang perlu memupuk rasa tertarik pada hal-hal yang menunjang kesejahteraan umum sebagai halhal yang pantas diinginkan bagi perkembangan dan perwujudan dirinya sendiri sebagai manusia dan tidak melakukan sesuatu untuk orang lain melulu karena itu suatu kewajiban. Erat berkaitan dengan ini adalah usaha Dewey untuk menujukkan bahwa pikiran dan perasaan, pertimbangan akal dan keinginan hati tidak perlu dipertentangkan satu sama lain, melainkan perlu dipadukan kalau orang mau membentuk pribadi moral yang utuh. Bagi Dewey, keinginan yang merupakan suatu "dorongan untuk maju dari makhluk hidup," adalah sesuatu yang bersifat kodrati pada manusia dan perlu diartikulasikan. Terpisah dari pertimbangan akal, keinginan memang cenderung menjadi liar dan memperbudak. Akan tetapi, terpisah dari keinginan, akal dapat menjadi dingin dan membosankan, serta sebagai akibatnya hidup sendiri menjadi sendu dan kurang vitalitas. Dalam pemikiran Dewey, keinginan merupakan sesuatu yang menjadi daya dorong dan kekuatan untuk mewujudkan suatu kebaikan atau mencapai suatu tujuan tertentu yang dalam konteks lingkungan hidupnya telah ditetapkan: “Betapapun masak dikaji dan rasional suatu objek pikiran, kalau objek itu tidak menimbulkan keinginan, maka objek itu akan tetap tak berdaya." ${ }^{13}$

Sehubungan dengan gagasan tersebut Dewey mengkritik teori moral Kant yang terlalu berat sebelah mengutamakan peran akalbudi dan amat mencurigai perasaan dan keinginan manusia, bahkan termasuk afeksi terhadap orang lain, sebagai suatu hal yang pada dasarnya tak teratur dan bersifat mementingkan diri (selfish). Dalam pemikiran Kant, suatu 
tindakan dinilai benar secara moral hanya kalau motivasi untuk melakukan tindakan itu sungguh murni. Untuk menjamin hal ini, tindakan harus dilakukan demi rasa hormat terhadap hukum moral yang mewajibkan dia untuk melakukannya dan tidak boleh didasarkan atas dorongan perasaan dan keinginan kodrati manusia. Berkaitan dengan ini Dewey secara karikatural menyatakan bagaimana dalam teori moral Kant seorang ibu terpaksa harus menekan perasaan dan afeksi kodratinya terhadap anaknya sendiri untuk sungguh bertindak moral dalam mencintai dan memelihara anaknya.

Bagi Dewey tidak ada sesuatu yang secara intrinsik buruk pada dorongan perasaan dan keinginan kodrati manusia. Ia mengkritik teori moral yang terlalu menekankan askese atau matiraga dan bahkan menganggapnya sebagai tujuan pada dirinya sendiri: "Alih-alih menjadikan penundukan keinginan sebagai tujuan pada dirinya sendiri, hal itu mesti diperlakukan sebagai fungsi yang perlu dalam pengembangan keinginan yang akan menghasilkan kebaikan yang lebih inklusif dan lestari."14 Moralitas haruslah lebih menekankan hal-hal yang positif daripada menekankan pergulatan yang tak kunjung henti menghadapi dorongan kekuatan yang menggoda (seductive) dari hal-hal yang kurang baik. ${ }^{15}$ Menurut pendapat Dewey, lebih baik pada setiap kesempatan memupuk perasaan dan keinginan pada hal-hal baik yang dapat disetujui oleh refleksi pikiran kita daripada menekan mereka, sebab "menolak memberi tempat pada unsur kepuasan langsung dalam moral, berarti melemahkan daya tarik yang menggerakkan hati dari hal-hal yang pantas disetujui oleh pikiran." ${ }^{16}$ Dalam pernyataannya tentang tempat diri pribadi manusia dalam kehidupan moral, Dewey juga menekankan perlunya integrasi antara pikiran dan perasaan atau keinginan hati. Dia mengatakan: "Masalah pokok dalam moral adalah bagaimana membentuk diri pribadi yang awalnya memiliki kecenderungan-

14 Ibid., pp. 54.

15 Ibid., pp. 57.

16 Ibid., pp. 59. 
kecenderungan impulsif menjadi diri pribadi yang bertindak bebas, dan dalam pribadi yang bertindak bebas tersebut keinginan dan perasaan terpusat pada nilai-nilai yang berlaku umum; dengan kata lain, minatnya terpusat pada hal-hal yang menyumbang pengayaan hidup semua orang." 17

Sebagai rangkuman atas bagian kedua makalah ini, dapatlah dikatakan bahwa, pertama, bagi Dewey suatu tindakan manusia disebut benar atau perilakunya baik secara moral kalau tindakan itu, dilihat dari sisi subjek pelaku tindakan, menunjang perkembangan dan perwujudan dirinya sebagai manusia. Suatu tindakan dinilai menunjang perkembangan dan perwujudan diri seseorang sebagai manusia kalau tindakan itu mewujudkan ends-in-view, yakni tujuan-tujuan kegiatan yang dalam perspektif perkembangannya sampai sekarang diperhitungkan akan menunjang proses reintegration orang tersebut dalam lingkungan hidupnya atau memulihkan equilibrium yang terganggu. Tindakan yang mewujudkan ends-in-view adalah tindakan yang dipikirkan masakmasak kemungkinan-kemungkinan akibatnya bagi diri sendiri dan orang lain. Secara kodrati manusia adalah makhluk sosial, dan karena itu, seorang pelaku moral akan semakin mengembangkan dan mewujudkan dirinya sebagai manusia apabila tindakannya mengindahkan hubungannya dengan orang lain dan sedapat mungkin memperkaya pengalaman semua pihak yang terkait dalam lingkungan hidupnya. Kedua, Dewey berpendapat bahwa setiap orang perlu memupuk rasa tertarik pada hal-hal yang menunjang kesejahteraan umum sebagai hal-hal yang pantas diinginkan bagi perkembangan dan perwujudan dirinya sendiri sebagai manusia dan tidak melakukan sesuatu untuk orang lain melulu karena itu suatu kewajiban. Orang semakin mengembangkan dan mewujudkan dirinya sebagai manusia kalau hatinya semakin dapat menginginkan hal-hal yang pantas disetujui oleh refleksi pikirannya dan bertindak secara bebas berdasarkan tanggung jawab pribadinya. Dengan

17 Ibid., pp. 168. 
kata lain, orang semakin mengembangkan dan mewujudkan dirinya sebagai manusia kalau dalam tindakan-tindakannya, hati dan pikirannya semakin terintegrasi.

\section{EVALUASI}

Sebagai evalusi atau tanggapan terhadap pemikiran moral Dewey sebagaimana dipaparkan di atas, berikut akan diberikan beberapa catatan yang mencoba menunjukkan relevansi pemikiran tersebut dewasa ini dan sekaligus memberi evaluasi kritis terhadap beberapa gagasan pokok yang ia kemukakan.

\section{GAGASAN POSTMODERNIS DAN KOMUNITARIS}

Menempatkan pemikiran moral Dewey sebagaimana telah dipaparkan di atas dalam konteks wacana filsafat dewasa ini, hal pertama yang muncul dalam pikiran saya dan pantas dicatat adalah adanya unsur gagasan postmodernis dan komunitaris dalam pemikirannya. Unsur gagasan postmodernis dalam pemikiran Dewey, misalnya, nampak dari penolakannya terhadap paham essensialisme dalam memahami manusia, penekanannya pada pluralitas kebaikan moral serta kontekstualitas dalam memahami dan menilai suatu tindakan. Baik pemikiran Dewey maupun pemikiran postmodernis bernada relativis dan menekankan heterogenitas serta keunikan situasi, sementara unsur komunitaris dalam pemikiran Dewey nampak dari penekanannya pada keterkaitan setiap individu manusia dengan lingkungan alam dan sosialnya. Setiap individu manusia selalu lahir dan dibesarkan dalam lingkungan masyarakat dengan tradisi tertentu. Ia bukan individu yang secara atomistik berbeda dan bahkan terpisah dari individu-individu yang lain. Identitas diri tidak dapat sama sekali dilepaskan dari identitas sosialnya. Seperti sudah dinyatakan di atas, bagi Dewey seorang individu manusia semakin mengembangkan dan mewujudkan kemanusiaan semakin ia mengembangkan sosialitasnya. Ends-in-view sebagai tujuan dan puncak kegiatan tercapai bila reintegrasi dengan lingkungannya terjadi atau bila equilibrium yang terganggu dalam interaksi dengan lingkungan bisa dipulihkan. 
Kenyataan adanya unsur postmodernis dalam pemikiran Dewey kiranya cukup menarik untuk disimak karena Dewey sendiri dalam konteks historisnya jelas seorang modernis. Ia menjunjung tinggi sains dengan rasionalitas ilmiah teknologis dan ideologinya tentang kemajuan peradaban yang dibawanya. Dewey mencita-citakan diterapkannya metode ilmiah dalam seluruh bidang kehidupan manusia, termasuk bidang kehidupan sosial dan moral, sedangkan postmodernisme mencurigai dan bahkan menolak konsep rasionalitas tunggal dan uni-versal produk zaman Pencerahan. Postmodernisme menganggap konsep macam itu bersifat totaliter, buah dominasi budaya Eropasentrisme. Postmodernisme menekankan paham rasionalitas yang plural dan lokal.

Mengenai unsur komunitaris dalam pemikiran moral Dewey, kiranya hal itu ada hubungannya dengan model biologis yang dia ambil dalam memahami pengalaman manusia. Seperti sudah dikemukakan di atas, dalam model itu manusia digambarkan sebagai organisme yang perlu terus berinteraksi, atau istilahnya sendiri, bertransaksi dengan lingkungannya untuk dapat hidup dan berkembang. Selain itu, karena filsafat Dewey dalam banyak hal sangat dipengaruhi oleh pemikiran Hegel, maka tidak mengherankan bahwa pemikiran moral Dewey tidak terlalu jauh dari konsep Sittlichkeit Hegel, suatu konsep yang dapat dikatakan merupakan inspirasi dasar bagi aliran komunitarisme. Dalam kritiknya terhadap formalisme teori moral Kant seraya mempertahankan unsur positifnya dalam segi penekanan pentingnya otonomi subjek pelaku tindakan dalam moralitas, Hegel menunjukkan bahwa substansi atau isi material moralitas secara konkret terjelma dalam tradisi. Subjek pelaku moral tidak hidup dalam vacuum. Dalam bahasa komunitarisme, tradisi atau konteks sosial, historis, dan kultural berikut relasi-relasi dan komitmen yang telah dibuat seorang subjek pelaku moral akan selalu menjadi kondisi objektif yang perlu diindahkan dalam deliberasi dan penentuan tentang kebaikan konkret yang mau dan dapat diwujudkan. 
Subjek pelaku moral adalah seorang pribadi konkret, anggota suatu komunitas dan anak zaman tertentu, dan bukan individu abstrak, impersonal dan ahistoris.

\section{MASALAH INFINITE REGRESS}

Salah satu kritik terhadap teori moral Dewey berkenaan dengan penolakannya terhadap gagasan adanya final end berdasarkan finalitas kodrat manusia dan sebagai gantinya ia menekankan peran ends-inview, adalah bahwa penolakan itu akan membuat teorinya jatuh ke dalam masalah "infinite regress." 18 Dengan masalah "infinite regress" dimaksudkan tidak adanya pendasaran yang secara logis memberi pembenaran terakhir (ultimate justification) bagi proses penalaran yang ada. Dalam konteks teori moral Dewey, karena adanya final end yang berlaku universal ditolak, dan yang ada adalah serangkaian ends-in-view, maka pembenaran terhadap setiap end-in-view hanya bisa secara prosesif konsekuensial dan tidak pernah secara definitif dilakukan. Benar-salahnya penentuan suatu end-in-view hanya dapat dilihat dari konsekuensi selanjutnya ketika hal itu tercapai, yakni dilihat dari apakah end-in-view itu berhasil mengatasi masalah yang dihadapi dan membawa kemajuan, pertumbuhan serta perbaikan keadaan yang sudah ada. Demikianlah seterusnya dengan end-in-view selanjutnya, dan end-in-view selanjutnya, tanpa akhir.

Dewey sendiri rupanya sadar akan kemungkinan munculnya kritik macam itu terhadap gagasannya yang menolak adanya final end. Ia mencoba menangkisnya dengan menjelaskan bahwa kritik macam itu muncul dari paham a priori bahwa hanya kalau ada final end yang dapat memberi pembenaran terakhir, maka suatu pernyataan mempunyai dasar pembenaran, sedangkan kalau tidak, maka dianggap tanpa dasar pembenaran sama sekali. Bagi Dewey, yang dalam peristilahan Richard Rorty seorang "anti-foundationalist," paham seperti itu tidak harus diikuti

18 Kritik semacam itu, misalnya, pernah dilontarkan oleh Robert J. Roth, "Naturalistic Ethics: Problem of Method," dalam The New Scholasticism 40 (1966): 294-295. 
dan bahkan pantas ditolak. Menurut Dewey, setiap end-in-view dirumuskan berdasarkan kondisi negatif yang secara konkret dihadapi (seperti keingingan yang perlu dipuaskan, kebutuhan dan kekurangan yang perlu dipenuhi, keburukan yang perlu diperbaiki, situasi konflik yang perlu diatasi), dan end-in-view itu dinilai kebenarannya berdasarkan berhasil tidaknya dalam memperbaiki kondisi negatif tersebut. Berdasarkan model pengalaman estetis, setiap end-in-view-sebagai penyatuan berbagai macam kegiatan dalam proses interaksi seseorang atau sekelompok orang dalam masyarakat dengan lingkungannya dan sekaligus pemberian makna pada keseluruhan kegiatan itu-dalam arti tertentu bersifat final pada dirinya dan tidak memerlukan final end abstrak universal yang melingkupi semuanya dan bersifat ontologis. Karena proses interaksi dengan lingkungan terus berjalan, dan baik manusia maupun lingkungannya terus berubah, finalitas itu memang bersifat sementara. Tetapi dilihat dari perspektif keseluruhan kegiatan sebelumnya yang menuju kepadanya dan dituntut oleh kondisi situasi permasalahan yang dihadapi, setiap end-in-view dalam arti itu bersifat final. ${ }^{19}$

Argumen Dewey untuk menangkis kritik di atas, walaupun berhasil menunjukkan bahwa masalah "infinite regress" hanya muncul kalau orang menerima asumsi bahwa kalau tidak ada dasar pembenaran terakhir lalu tidak ada pembenaran sama sekali, tetap belum membebaskan teorinya dari berbagai kesulitan fundamental. Kesulitan itu, misalnya, kalau ends-in-view hanya bisa ditentukan berdasarkan kondisikondisi negatif sebelumnya yang perlu diatasi dan dapat dinilai baikburuknya hanya dari cocok-tidaknya atau berhasil-tidaknya dalam mengatasi kondisi negatif tersebut, lalu atas dasar apa kenegatifan kondisi itu sendiri dinilai dan ditentukan? Tidak semua keinginan yang muncul perlu dipuaskan, tidak semua yang dirasa sebagai kekurangan memang secara objektif merupakan kekurangan yang perlu dipenuhi. Mana tolok ukur untuk membedakannya? Kemudian kalau nilai moral yang dasariah adalah pertumbuhan, kemajuan atau perbaikan keadaan

19 Dewey, Theory of Valuation, pp. 45,47-48. 
sebelumnya, atas dasar apa dan bagaimana hal-hal itu mau dinilai dan diputuskan tanpa adanya konsep umum dan abstrak tentang kebaikan manusiawi sebagai tujuan ideal untuk dicapai dan tolok ukur untuk menilai? Orang hanya dapat menilai apakah langkah yang dibuatnya itu maju atau mundur kalau ada suatu titik tujuan yang diarah. Kalau tidak, orang bisa mengira melangkah maju terus, padahal sesungguhnya menyamping atau melingkar dan justru semakin menjauh dari titik tujuan. Kesulitan lain dengan mengambil model aktivitas "problem solving" dalam memahami proses penilaian dan putusan moral dan melihat tindakan baik sebagai tindakan yang akibatnya berhasil menyelesaikan masalah yang secara konkret dihadapi, teori etika pragmatik Dewey, sebagaimana etika utilitarisme, dapat bertentangan dengan prinsip keadilan dan tidak memperhitungkan segi penting dalam moralitas, yakni motivasi tindakan. Pemecahan persoalan melulu secara pragmatik sering membawa korban diabaikannya hak-hak individu, dan apa yang secara pragmatik memecahkan persoalan yang dihadapi tidak selalu dengan sendirinya baik secara moral. Penilaian moral juga harus memperhatikan motivasi si pelaku tindakan. Tindakan yang berakibat baik, tetapi dilakukan dengan motivasi yang buruk, akan mengurangi kualitas kebaikan tindakan tersebut.

\section{PENDEKATAN POSITIF DALAM PENDIDIKAN MORAL}

Unsur penting lain dari pemikiran moral Dewey yang menurut saya relevan dan pantas dicatat pula di sini adalah penekanannya pada pendekatan positif dalam pendidikan moral. Seperti dinyatakan di atas, menurut Dewey, moralitas haruslah lebih menekankan hal-hal yang positif daripada menekankan pergulatan yang tak kunjung henti menghadapi dorongan kekuatan yang menggoda (seductive) dari hal-hal yang kurang baik. Dengan pendekatan positif dalam pendidikan moral dimaksudkan pendekatan yang tidak terlalu menekankan larangan ini dan larangan itu atau sanksi ini dan sanksi itu bila terjadi pelanggaran, tetapi secara positif memupuk hasrat dan keinginan akan hal-hal yang tahan uji terhadap refleksi kritis pikiran dan menyejahterakan banyak orang. Dewey mempunyai sikap positif terhadap hasrat dan keinginan 
manusia. Hasrat dan keinginan manusia pada dasarnya baik. Mereka tidak perlu ditekan dan bahkan dimatikan. Yang perlu hanyalah diatur dan disalurkan. Di sinilah akal budi berperan. Hasrat dan keinginan perlu diintegrasikan dengan akal budi. Bila integrasi itu terjadi, Dewey percaya bahwa manusia dapat dengan bebas dan gembira menghendaki untuk terlibat dalam kegiatan bersama yang menunjang kesejahteraan umum.

Pendidikan moral yang terlalu menekankan banyak larangan dan sanksi pelanggaran serta perlunya terus bertempur melawan dorongan jahat manusia mungkin dapat membuat peserta didik hidup tertib dan hati-hati, tetapi penuh ketakutan dan mudah dihinggapi rasa salah. Ia tidak akan bertumbuh menjadi pribadi yang gembira, berani, penuh gairah, semangat, berinisiatif dan kreatif. Kiranya lebih baik bagi seorang peserta didik bahwa ia pernah keliru karena berbuat sesuatu daripada tidak pernah keliru karena terus menerus takut berbuat sesuatu.

\section{DAFTAR RUJUKAN}

Avineri, Shlomo and de-Shalit, Avner, eds. Communinitarianims and Individualism. Oxford: Oxford University Press, 1992.

Dewey, John. Art As Experience. New York: Capricorn Books, G.P. Putnam's Sons, 1958.

. Experience and Nature. La Salle, Ill: Open Court, 1971.

1962. . Individualism Old and New. New York: Capricorn Books, - Reconstruction in Philosophy. Boston: Beacon Press, 1972. . Theory of the Moral Life. New York: Holt, Rinehart and Winston, 1960.

. Theory of Valuation. Chicago: The University of Chicago Press, 1966.

Rorty, Richard. Consequences of Pragmatism. Minneapolis: University of Minnesota Press, 1982. . Philosophy and Social Hope. New York: Penguin Books, 1999.

Roth, Robert J. John Dewey and Self-Realization. Englewood Cliffs, NJ: Prentice-Hall, 1962.

. "Naturalistic Ethics: Problem of Method." The New Scholasticism, 40 (1966): 285-311. 